\title{
Bio-chemical composition of Catfish, Rita rita from Indus River near Jamshoro
}

\author{
Parvaiz Khan ${ }^{1}$, Naeem Tariq Narejo ${ }^{1}$, Shaista Jalbani ${ }^{1}$, Abdul Jabbar \\ Laghari $^{2}$ and Fahmida Memon ${ }^{3}$ \\ 1. Department of Freshwater Biology and Fisheries, University of Sindh, Jamshoro-Pakistan \\ 2. Center for Advanced Research in Chemical Sciences, University of Sindh, Jamshoro-Pakistan \\ 3. Department of Physiology, University of Sindh, Jamshoro-Pakistan \\ *Corresponding author's email: $\underline{\mathrm{dr} \_n t n a r e j 046 @ y a h o o . c o m}$ \\ Citation \\ Parvaiz Khan, Naeem Tariq Narejo, Shaista Jalbani, Abdul Jabbar Laghari and Fahmida Memon. Bio-chemical \\ composition of Catfish, Rita rita from Indus river near Jamshoro. Pure and Applied Biology. Vol. 6, Issue 1, pp47- \\ 52. http://dx.doi.org/10.19045/bspab.2016.50165
}

\begin{tabular}{llll}
\hline \hline Received: 14/10/2016 & Revised: 14/12/2016 & Accepted: 18/12/2016 & Online First: 21/12/2016 \\
\hline
\end{tabular}

\section{Abstract}

For biochemical composition of catfish Rita rita, 60 specimens ranged from $10.1-40.0 \mathrm{~cm}$ and $75.0-632.0 \mathrm{~g}$ in total length and weight respectively were collected from Indus river near Jamshoro during November 2015 - January 2016. The study on biochemical composition was enumerated from fillets of head, trunk and tail region at 3 different length groups (small, medium and large). Results of study revealed that highest $\%$ of moisture was observed from head region (84.5) followed by tail (83.6) and lowest was observed (82.5) in trunk, in case of \% protein contents highest was observed from tail (12.1) followed by trunk (10.43) and lowest in head (8.33), \% fat contents was observed highest in head (6.83) followed by trunk (6.7) lowest in tail (3.7) while ash was observed highest in trunk (3.1) followed by tail (2.7) and lowest in head (2.0) at each length group.

Keywords: Bio-chemical; Catfish; Rita rita; Indus river; Jamshoro

\section{Introduction}

Fish is the only source of animal protein exhibits in high production capacity in small unit [1]. Flesh of fish is also considered useful for the control of eye and cardiovascular tissues. Fish growth is effected by numerous factors such as season, temperature, food space and physical activity [2]. Fish are cold blooded and survive in water and any change in their media directly affected to the fish. Changes may be in size shape length, weight or may be related to lipid, protein and fat [3]. Body composition is a good indicator of a physiological health of fish. Its analysis provides an idea about percentage of moisture, protein, fat and ash and their relation into size and condition factor [4]. The water percentage $\%$ in fish body is good indicator for the relative content of energy protein and lipids. It is inversely proportion to relative lipids, protein and energy contents [5] as lower the water percentage in fish greater will be percentage of lipid and protein so high the energy content in fish [6]. Fish body mainly composes of fat, protein and inorganic content while carbohydrate and some other non-protein part of usually in negligible quantities for accessing the nutritional value of fish food. Biochemical analysis of fat, ash and protein is very important) [7] which ensure the 
eating quality as well as fish nutritional values [8]. Fresh water catfish Rita rita belongs to family Bagridae and genus Rita. This fish was found to abundant contently in Pakistan, India and Myanmar [9]. It's important commercial fish due to its meat taste [10]. However it has become critically endangered and red listed. Many scientist works on different aspects of this commercially important food fish like [11, 12] but no literature is available on body composition of this important catfish. So, present work will be useful for consumers to get nutritional rich fillet of fish for consumption.

\section{Materials and methods}

60 specimens of Rita rita were collected from Indus river near Jamshoro during November 2015 - January 2016. The experimental fish was ranged from 10.1$40.0 \mathrm{~cm}$ and $75.0-632 \mathrm{~g}$ in length and weight respectively. The fish divided into three fillet /region (head, trunk and tail region) at three length groups stated from 10.1-20.0, 20.1-30.0cm. Live specimen of experimental fish was transported in plastic container to the laboratory Institute of Biochemistry, University of Sindh, Jamshoro. Fish were removed from plastic container and were killed, blotted dry with a paper towel and weight on electronic digital balance (Model CT, 1200-s, made in USA). Total length of fish was measured to the nearest $0.1 \mathrm{~mm}$ from tip of maxilla to the tip of longest caudal fin ray using measuring tap then placed in pre weight aluminum foil, labeled the file placed the spaceman in foil and dried to constant mass by slow heating in a oven at $700^{\circ} \mathrm{C}$ to analyzed the quantity of moisture, protein, ash and fat contents in each part in relation to length of fish. Each dried part was crushed and powder in pastel and mortar, homogenized in a moulinex electoral blander and preserved in plastic bottle with proper labeling. In nutrition the first and most important is to know the quality of flesh, for that purpose some basic quality parameters were analyzed to find their nutritional value, which help to calculate environmental suitability for fish included as total moisture contents, total protein contents, total fat contents and total Ash contents. Water contents was measured by weighing difference before and after oven drying at $65-80^{\circ} \mathrm{C}$ in an electronic oven (Memmert) each dry specimens was powdered and homogenized for further analysis. The protein concentrations in (Head, Trunk and Tail) at different length were measured by the method reported by [13] and the total protein content was calculated from the standard curve. The fat contain was estimated by method of [14]. Ash content was determined by dry aishing method using muffel furance (Sybron thermoline 1300) for ten hours at $600{ }^{\circ} \mathrm{C}$ Dry extraction method was used to determine fat content following [14]. Carbohydrates are found in negligible amount in a fish $[15,16]$ hence no attempt was made in the present study to calculate carbohydrate contents.

\section{Results}

An investigation was conducted to determine the proximate composition of head, trunk and tail region of catfish Rita rita at three different length groups. 60 specimens of Rita rita were collected from Indus river near Jamshoro during November 2015 - January 2016. Data on total length, total weight, wet weight of head, trunk and tail of Rita rita presented in (Table 1). The size ranged from $10.1-40.0 \mathrm{~cm}$ and75.0$632.0 \mathrm{~g}$ in total length and weight respectively. The study on biochemical composition of catfish, Rita rita was enumerated from the fillet of head, trunk and tail region of Rita rita from 3 different length groups. Results of study revealed that highest \% of moisture was observed from head (84.5) followed by tail (83.6) and lowest was observed (82.5) in trunk, in case 
of $\%$ protein contents was found to be highest from tail (12.1) followed by trunk ( 10.43) and lowest in head (8.33), \% fat contents was observed highest in head (6.83) followed by trunk (6.7) lowest in tail (3.7) while ash was observed highest in trunk (3.1) followed by tail (2.7) and lowest in head (2.0) at each length group and presented in Tables (2, 3 and 4).

Finally concluded that fillet of Rita rita from tail region was considered excellent and healthier part in terms of nutrition in relation to head and trunk.

Table 1. Data on total length, total weight, wet weight of head, trunk and tail of Rita rita from Indus river near Jamshoro, Sindh, Pakistan

\begin{tabular}{|l|l|l|l|l|l|l|}
\hline \multicolumn{2}{|l|}{ Total group } & \multicolumn{2}{|l|}{ Total weight (g) } & $\begin{array}{l}\text { Mean Wet } \\
\text { weight of HL }\end{array}$ & $\begin{array}{l}\text { Mean. Wt } \\
\text { weight of } \\
\text { trunk }\end{array}$ & $\begin{array}{l}\text { Mean. Wet } \\
\text { weight of tail }\end{array}$ \\
\hline Range & Mean & Range & Mean & & $39 \pm 1.0$ & $7.5 \pm 0.5$ \\
\hline $10.1-20.0$ & $16.5 \pm 0.5$ & $60-90$ & $75 \pm 1.0$ & $25 \pm 1.0$ & $39.0 \pm 2.0$ \\
\hline $20.1-30.0$ & $26.2 \pm 0.8$ & $180-400$ & $290 \pm 2.0$ & $97 \pm 1.0$ & $150 \pm 1.0$ & $29.0 \pm 0$ \\
\hline $30.1-40.0$ & $37.0 \pm 1.0$ & $500-764$ & $632 \pm 2.8$ & $210 \pm 1.0$ & $320 \pm 1.0$ & $32.0 \pm 2.0$ \\
\hline
\end{tabular}

Table 2. Bio-chemical composition of head region of Rita rita from Indus river near Jamshoro, Sindh, Pakistan

\begin{tabular}{|l|l|l|l|l|l|l|l|}
\hline \% Moisture & \multicolumn{2}{l|}{ \% Protein } & \%Fat & \multicolumn{2}{l|}{ \% Aish } \\
\hline Range & Mean & Range & Mean & Range & Mean & Range & Mean \\
\hline $87.2-88.5$ & $87.8 \pm 0.2$ & $6.42-6.97$ & $6.7 \pm 1.3$ & $4.8-5.70$ & $5.2 \pm 0.8$ & $1.43-1.7$ & $1.5 \pm 0.5$ \\
\hline $84.5-85.37$ & $84.9 \pm 0.1$ & $8.85-9.42$ & $9.1 \pm 0.9$ & $5.37-6.24$ & $5.7 \pm 0.3$ & $1.88-3.2$ & $2.4 \pm 0.6$ \\
\hline $80.21-81.9$ & $81.0 \pm 1.0$ & $8.16-10.18$ & $9.2 \pm 0.8$ & $9.89-10.26$ & $9.6 \pm 0.4$ & $1.58-2.9$ & $2.1 \pm 0.9$ \\
\hline & 84.5 & & 8.33 & & 6.83 & & 2.0 \\
\hline
\end{tabular}

Table 3. Bio-chemical composition of trunk region of Rita rita from Indus river near Jamshoro, Sindh, Pakistan

\begin{tabular}{|l|l|l|l|l|l|l|l|}
\hline \%Moisture & \multicolumn{2}{l|}{ \% Protein } & \%Fat & \% Aish \\
\hline Range & Mean & Range & Mean & Range & Mean & Range & Mean \\
\hline $83.52-85.53$ & $84.60 \pm 1.0$ & $10.04-11.12$ & $10.7 \pm 0.7$ & $3.18-4.89$ & $4.1 \pm 0.9$ & $3.81-4.81$ & $3.9 \pm 0.3$ \\
\hline $81.07-82.61$ & $81.9 \pm 0.1$ & $8.09-10.81$ & $9.9 \pm 0.1$ & $6.43-8.18$ & $7.6 \pm 0.4$ & $2.24-3.53$ & $2.8 \pm 0.2$ \\
\hline $80.63-80.89$ & $80.7 \pm 0.3$ & $9.19-12.30$ & $10.7 \pm 0.7$ & $7.75-9.11$ & $8.4 \pm 0.6$ & $2.51-3.15$ & $2.8 \pm 0.2$ \\
\hline & 82.4 & & 10.43 & & 6.7 & & 3.1 \\
\hline
\end{tabular}

Table 4. Bio-chemical composition of tail region of Rita rita from Indus river near Jamshoro, Sindh, Pakistan

\begin{tabular}{|l|l|l|l|l|l|l|l|}
\hline \% Moisture & \multicolumn{2}{l|}{ \% Protein } & \%Fat & \% Aish \\
\hline Range & Mean & Range & Mean & Range & Mean & Range & Mean \\
\hline $85.74-87.96$ & $86.7 \pm 0.3$ & $9.10-11.70$ & $11.0 \pm 1.0$ & $1.39-2.78$ & $2.2 \pm 0.8$ & $2.86-3.07$ & $2.9 \pm 0.9$ \\
\hline $82.44-84.79$ & $83.7 \pm 0.3$ & $11.67-12.46$ & $12.1 \pm 0.9$ & $2.70-3.90$ & $2.6 \pm 0.4$ & $2.25-2.96$ & $2.6 \pm 0.4$ \\
\hline $79.28-81.25$ & $80.5 \pm 0.5$ & $12.68-13.92$ & $13.2 \pm 0.8$ & $5.37-6.80$ & $6.4 \pm 0.6$ & $2.09-3.07$ & $2.7 \pm 0.3$ \\
\hline & 83.6 & & 12.1 & & 3.7 & & \\
\hline
\end{tabular}

\section{Statistical analysis}

Analysis of variance (ANOVA) was used to compare means of the proximate composition data. Further analysis was carried out where there were significant differences $(p<0.05)$ using Least Significant Difference [17]. 


\section{Discussion \\ Moisture}

From the above results, the moisture percentage (\%) was found 87.2-88.5 \pm 0.2 . This result coincides with the findings of [18] in Macrognathus aculetus, [19] in Puntis gonionotus and [20] in Amblypharyngodon mola, Puntis chola, Gudusia chapra and in Puntis atherinoides. These findings also agreed with observation of [21] in several freshwater fish species. Usually moisture and lipid contents in fish fillets are inversely related and their sum is approximately $80 \%$ [22].

\section{Protein}

The protein content $(\%)$ was $13.92 \pm 0.8$ which is more or less coincides with the findings of [20] in G. chapra and P. chola. The results of protein percentage in Labeo rohita and Labeo calbasu are in accordance with the current research. The range of protein contents as given by [23] which were $16.6 \%$ and $14.7 \%$ respectively are in agreement with present findings. [24] also found the result of protein percentage in silver pomfret (Stromateus cinereus) was $16.70 \%$ and Ribbon fish (Trichiurus haumela) was $16.6 \%$ while the percentage was much higher in Clarias gariepinus $19.64 \%$ and in Cirrhinus reba $19.74 \%$ found by $[25,26]$ respectively are similar with the study.

\section{Fat}

The fat content $(\%)$ was $7.75 \pm 1.52$. The result is very much higher than some other commercial native fish of Bangladesh like Channa striatus, Ophiocephalus punctatus and Heteropneustes fossilis whose fat content was $0.64 \%, 1.08 \%$ and $1.23 \%$ respectively estimated by [27] are found to be similar with present study.

\section{Ash}

The ash content was 2.68-3.07 which was nearer to the result of [28] in Tilapia guinensis and Tilapia melanotheron which contained $1.30 \%$ and $1.06 \%$ respectively.
[20] Stated that A. coila and in A. mola also find similar ash percentage ranged between $1.6 \%$ to $3.2 \%$. The ash content of the $O$. rubicundus was also more or less similar to that of small indigenous species. [29] found higher amount of ash content in Clarias. gariepinus $(3.06 \%)$ than the studied fish, while [30] in his experiment found lower amount of ash content in six freshwater fishes Labeo rohita (1.31\%), Catla catla (0.93\%), Cirrihinus cirrhosus (1.40\%), Labeo calbasu (1.02\%), Mystus seeghala $(0.91 \%)$ and Wallago attu $(0.72 \%)$. According to [31], variation in proximate composition of fish flesh may vary with species variation, season, age and feeding habit of the fish. Generally moisture content showed inverse relationship with lipid content also found in the Pungus fish. The inverse relationship has also been reported in marine fishes such as Mugil cephalus [32]; Sarda sarda [33].Therefore, this fish can play a significant role to fulfill the nutrient demand of the people in Pakistan.

\section{Conclusion}

Results of present study revealed that tail region possess $(11.04-13.29 \%)$ highest percentage of protein followed by trunk region (10.43) and lowest in head region (8.33) at each length group.

Finally concluded that fillet of Rita rita from tail region was considered excellent and healthier part in terms of nutrition in relation to head and trunk.

\section{Authors' contributions}

Conceived and designed the experiments: NT Narejo, Performed the experiments: P Khan \& AJ Laghari, Contributed reagents/ materials/ analysis tools: Center for Advanced Research in Chemical Sciences and Department of Physiology, University of Sindh, Jamshoro, Wrote the paper: P Khan \& NT Narejo.

\section{References}

1.Pillay TVR (1993). Aquaculture: Principals and practices. Fishing news 
books, Blakwell Scientific Publication, Ltd.

2.Ali M, Iqbal F, Salam A, Iram S \& Athar M (2005). Comparative study of the body composition of different fish species from brackish water pond. Int $J$ Environ Sci Tech 2: (3) 229-232.

3.Weatherly AH \& Gill HS (1987). The biology of fish growth. Academic Press, London

4.Shammi QJ \& Bhatnagar S (2002). Applied Fisheries. Agro. Bios. Jodhpur, India, 297302.

5.Dempson IB, Schwarz CJ, Shears M \& Furey G (2004). Comparative proximate body composition of Atlantic salmon with emphasis on fluvial and lacustrine habitats. J Fish Biol 64: 1257-1271.

6.Talwar PK \& Jhingran AG (1991). Inland fisheries of India and Adjecent countries. Vol. 1-2: Oxford and IBH publishing Co, Bombay, 721-722: 332333.

7.Kamal D, Khan AN, Rahman MA \& Ahmed F (2007). Biochemical composition of some small indigenous freshwater fishes from the River Mouri. Khulna, Bangladesh. Pak J Biol Sci 1:10 (9):1559-61.

8.Azam K \& Ali MY (2004) "Biochemical Assessment on Selected Fresh Fish," $J$ Bio Sci 4 (1): 9-10.

9.Tripathy B (1996) Mass hatching of olive sea turtle (Lepidochelys olivacea) along the Rushikulya muhana, East coast of India. Masters Dissertation. Berhampur University, Berhampur, Orissa. India pp77.

10. Anonymous (2000). Directive 2000/60/EC of the European Parliament Official Journal of the European Communities L 327

11. Laghari MY, Narejo NT, Mahesar H, Lashari PMK \& Abid M (2009). Length-weight relationship and condition of indigenous catfish, Rita rita (Hamilton) from cemented ponds of University of Sindh, Jamshoro. Sindh. Univ. Res. Jour. (Sci: Ser) 41 (2): 47-52.

12. Jafri SIH, Narejo NT \& Hussain SM (1998). Anomalous dorsal fin of a catfish Rita rita. Pakistan J Zool 30 (2): 159-161.

13. Lowry OH, Rosebrogh NJ, Farr AL \& Randall RJ (1951). Protein measurement with Folin phenol reagent. J Biol Chem 193: 265-275.

14. Bligh EG \& Dyer WJ (1959). A rapid method of total lipid extraction and purification. Canadian $J$ Biochem Physiol 37: 911-917.

15. Caulton MS \& Burseem E (1977). The relationship between changes in condition and body composition in young Tilapia rendaalli. J Fish Biol 2 1443-1450.

16. Salam A \& Davis PMC (194). Body composition of Northern pike (Esox lucius $\mathrm{L}$ ) in relation to body size and condition factor. J Fish Res 19: 193204.

17. Sokal RR \& Rohlf FJ (1987). Introduction to Biostatistics. W.H. Freeman and Company, New York. 363

18. Nabi RM \& Hossain MA (1989). Seasonal variation In the chemical composition and Caloric Content of Macrognathus aculeatus (Bloch) from the Chalan Beel Water. J. Asiatic Soc. Bangladesh 16(1): 61-66.

19. Islam MA, Hossain BBM, Bhuiyan AS \& Absar N (2003). Biochemical composition and nutritional value of Cirrhinus reba (Hamilton-1822) of Bangladesh. J Bio-Sci 11: 127-130.

20. Mazumder MSA, Rahman MM, Ahmed ATA, Begum M \& Hossain MA (2008). Proximate Composition of Some Small Indigenous Fish Species (SIS) in 
Bangladesh, J Int Sustain Crop Pord 3(4): 18-23.

21. Marias JFK \& Erasmus T (1977). Body composition of Mugil cephalus, Liza dumerili, Liza richardsoni and Liza tricuspidens (Teleostei: Mugilidae) caught in the Swartkops estuary. Aquaculture 10 (1): 75-86.

22. Food and Agriculture Organization (FAO). (1999). World production of fish, crustaceans and mollusks by major fishing areas. Fisheries Information and Data and Statistics Unit. (FIDI), Fisheries Department, FAO, Rome.33p.

23. Saha KC \& Guha BC (1939). Nutritional Investigation of Bengal Fish, India, pp. 921-927.

24. Gheyasuddin S, Rahman MA \& Kamal M (1979). Nutritive Qualities of Some of the Commercial Marine Fishes of Bangladesh. Journal of Bangladesh Agriculture 4(1): 34-38.

25. Osibona AO, Kusemiju K \& Akande GR (2006). Proximate Composition and Fatty Acids Profile of the African Catfish Clarias gariepinus, Journal of Life and Physical Science 3 (1): 1-5.

26. Mridha MA, Lipi SY, Narejo NT, Uddin MS, Kabir, MS \& Karim M (2005). Determination of Biochemical Composition of Cirrhinus reba (Hamilton, 1822) from Jessore, Bangladesh, Journal of Science \& Technology University Peshawar 29(1): 1-5.

27. Khuda MD, Khan HN \& Debnath JC (1962). Biochemical and nutritional studies on Pakistan Fish. Part 7.
Chemical Composition and Quality of the Traditionally Processed Fish, Pakistan J pp. 71-72.

28. Odukoya AM \& Abimbola AM (2010). Contamination assessment of surface and groundwater within and around two dumpsites. Int. J. Environ. Sci Tech 7 (2): 367-376.

29. Chakwu O \& Shaba IM (2009). Effect of drying method on proximate composition of cat fish (Clarias gariepinus). J.W. Agric Sci 5(1): 114116.

30. Devadsan K, Varma PHG \& Ventatraman R (1978). Studies on Frozen Storage Characteristics of Fillets from Six Species of Freshwater Fish. Fish Tech. India pp. 1-6.

31. Salam MA, Alam N, Nasiruddin M, Nabi R \& Howlader MZH (1995). Biochemical composition of body muscles and its caloric contents of tawes (Puntius gonionotius, Bleeder). Journal of Bangladesh Sci Res 13(2): 205-211.

32. Das S \& Sahu BK (2001). Biochemical composition and calorific content of fishes and shellfishes from Rushikulya Estuary, South Orissa coast of India. Indian J. Fish 48: 297-302.

33. Zaboukas N, Miliou H, Megalofonou P \& Lou MMA (2006). Biochemical composition of the Atlantic bonito Sarda sarda from the Aegean sea (Eastern Mediterranean Sea) in different stages of sexual maturity. $J$. Fish Biol 69: 347-362. 